the director, Mr R. H. C. Russell, claims to have shown a $£ 7$ million saving to industry for an expenditure of about $£ 700,000$.

\section{Linneans Wanted}

A LITTLE public relations can often do a lot of good, as the Linnean Society seems to have decided. The society, formed in 1788 by a splinter group from the Royal Society, concentrates on the biological sciences. It has now decided, in co-operation with the Department of Extramural Studies of London University, to run a series of lectures on the "Historical Background to Modern Botany" in an attempt to become better known and to attract more members, particularly keen amateurs. It is also running a natural history education programme with a course of lectures for 120 promising sixth form girls and boys, and has started a student associateship of the society to attract young members between the ages of 18 and 24 .

The society also intends to launch an appeal for $£ 100,000$. With the money it hopes to rehouse the valuable Linnaeus Collections and its library of 90,000 books, and to adapt the rooms in Burlington House which it acquired when the Royal Society moved out.

\section{More Nuclear Safeguards}

The US Atomic Energy Commission has provided further evidence of its concern for the safeguarding of nuclear materials of various kinds by its decision to establish a committee to provide technical advice on the subject. The chairman will be $\mathrm{Mr}$ J. Palfrey, a lawyer at Columbia University, who was a member of the $\mathrm{AEC}$ for four years until 1966. The fourteen ordinary members of the committee include scientists, industrialists and lawyers. The AEC says that it will rely on the committee for advice about the application of safeguards to particular problems as these occur, as well as for the development of general policy. Although the setting up of such a committee was not explicitly suggested by the Lumb panel on safeguards procedures which reported earlier this year, it is part and parcel of what seems to be a thorough review of safeguards procedures by the AEC.

At least three separate lines of argument have given. impetus to this tendency. The growth of the nuclear power industry in the United States is spectacular enough in itself to account for a renewal of interest in the subject. The amendment of the Atomic Energy Act which allows private companies to own nuclear fuels and to process them has emphasized the need for explicit criteria for a sharp line between the permissible and the illicit, and for means of ensuring that these criteria are observed. (Already one plutonium reprocessing plant and a number of fuel fabrication plants are operating under private ownership in the United States.) But it is also plain that international preoccupation with the treaty to limit the spread of nuclear weapons has made necessary a more explicit policy on safeguards, although the AEC as such can do very little in that respect but stand on the sidelines and show willing.

This is why the chief interest of the work of the new committee will be the way in which it helps to provide national precedents for what may eventually become international agreements on safeguards. In this sense it may already be significant that the AEC has decided to assign permanent inspectors to some at least of the privately owned processing plants-... the plant operated by Nuclear Services Incorporated for extracting plutonium from spent fuel, for example. Developments like these could well nudge the IAEA into the conviction that itinerant inspectors like those now based at Vienna may not always be able to exercise detailed control. There will also be great interest in the criteria for deciding what imprecisions in the safeguards system can be safely tolerated, which it will presumably be a part of the new committee's job to develop. It is less certain whether the committee will also pick up one of the more controversial recommendations of the Lumb panel-the notion that there should be stiff fines and prison sentences for people participating in breaches of the safeguards system. At first sight, there may be a little too much of James Bond in the suggestion that infringement of the regulations should expose people to the risk of five years in prison or fines of $\$ 10,000$, but if there are not criminal penalties of this kind, it may occasionally be extremely hard to know how conspirators should be dealt with under existing laws.

\section{New Reactors}

THe United Kingdom Atomic Energy Authority's steam generating heavy water reactor at Winfrith, Dorset (Nature, 214, 867; 1967), has been loaded with fuel and heavy water and the first stage of operation, at low power, has been reached. Construction started in May 1963, and the reactor is expected to be operat. ing at full power by the end of this year, when it will deliver $100 \mathrm{MW}$ of electricity into the national grid. The AEA has high hopes of the reactor in the export markets. In the size range $300-500 \mathrm{MW}$, the economics and fuelling of this reactor make it particularly attractive. New Zealand, which hopes to have about eight reactors by the late seventies, has already sent engineers to look at it.

The reactor has a pressure tube construction with heavy water as the moderator and natural water as coolant. Although the prototype at Winfrith uses slightly enriched uranium oxide fucl, the actual production reactor will use natural uranium. This may be an attraction in countries where pcople fear dependence on a small number of sources of fuel supply. The steam generated in the core passes dinectly to a turbo-alternator to generate electricity and not through a secondary cooling system.

The authority's VIPER reactor, intended for research, is also now in operation at Aldermaston, where it was designed and built. The reactor produces much more intense pulses of neutron and gamma radiation levels than those available from present steady state research reactors. At full power, thero are $3 \cdot 10^{17}$ fissions producing, in $500 \mu \mathrm{sec}, 10^{15}$ neutrons $/ \mathrm{cm}^{2}$ and a gamma-ray dose of 30,000 rads. The reactor power rises to a peak of $20,000 \mathrm{MW}$. Because the reactor does not have forced cooling, it must be allowed to cool at its own speed, and can generate only two pulses a day.

Pulses are produced by the rapid movement of a uranium fuel rod into and out of the core. This increases the reactivity of the reactor into the prompt 